\title{
Evolution of ancient Lake Ohrid: a tectonic perspective
}

\author{
N. Hoffmann ${ }^{1}$, K. Reicherter ${ }^{1}$, T. Fernández-Steeger ${ }^{2}$, and C. Grützner ${ }^{1}$ \\ ${ }^{1}$ Institute of Neotectonics and Natural Hazards, RWTH Aachen University, Aachen, Germany \\ ${ }^{2}$ Chair of Engineering Geology and Hydrogeology, RWTH Aachen University, Aachen, Germany
}

Received: 14 May 2010 - Published in Biogeosciences Discuss.: 16 June 2010

Revised: 3 September 2010 - Accepted: 21 September 2010 - Published: 29 October 2010

\begin{abstract}
Lake Ohrid Basin is a graben structure situated in the Dinarides at the border of the Former Yugoslavian Republic of Macedonia (FYROM) and Albania. It hosts one of the oldest lakes in Europe and is characterized by a basin and range-like geological setting together with the halfgraben basins of Korca, Erseka and Debar. The basin is surrounded by Paleozoic metamorphics in the northeast and north and Mesozoic ultramafic, carbonatic and magmatic rocks in the east, northwest, west and south. Paleocene to Pliocene units are present in the southwest. With the basin development, Neogene sediments from Pliocene to recent deposited in the lows. There are three major deformation phases: (A) NWSE shortening from Late Cretaceous to Miocene; (B) uplift and diminishing compression during Messinian - Pliocene; (C) vertical uplift and (N)E-(S)W extension from Pliocene to recent led to the basin formation. Neotectonic activity of the study area concentrates on $\mathrm{N}-\mathrm{S}$ trending normal faults that bound the Ohrid Basin eastwards and westwards. Seismic activity with moderate to strong events is documented during the last $2000 \mathrm{yrs}$; the seismic hazard level is among the highest in Albania and Macedonia. Activity of the youngest faults is evidenced by earthquake data and field observations. Morphotectonic features like fault scarps, a stepped series of active normal faults, deformed paleosols, a wind gap and fault-related hydrothermal activity are preserved around Lake Ohrid and allow delineating the tectonic history. It is shown that the Lake Ohrid Basin can be characterized as a seismogenic landscape. This paper presents a tectonic history of the Lake Ohrid Basin and describes tectonic features that are preserved in the recent landscape. The analysis of morphotectonic features is used to derive the deformation history. The stratigraphy of the area is summarized and concentrates on the main units.
\end{abstract}

\section{Introduction}

Lake Ohrid (693 m a.s.1.) in the southwest of the Former Yugoslavian Republic of Macedonia (FYROM, in the following referred to as Macedonia) and the east of Albania (Fig. 1) is regarded as one of the oldest lakes of Europe. Biological studies on endemic fauna give hints on a Pliocene age (Stankovic, 1960). With a length of $30 \mathrm{~km}$ and a width of $15 \mathrm{~km}$ it covers an area of $360 \mathrm{~km}^{2}$ that is larger than the neighboring lakes of Great Prespa and Small Prespa. The lake is surrounded by the Mokra Mountains to the west $(1.514 \mathrm{~m})$ and the Galicica Mountains to the east $(2.265 \mathrm{~m})$. The entire area can be characterized as a seismic landscape (Michetti and Hancock, 1997; Michetti et al., 2005). Historical earthquake data and instrumental seismicity prove that the Ohrid area is still tectonically active.

The lake is of scientific interest for a number of disciplines. Biologists carry out research on endemic species that evolved in the almost $300 \mathrm{~m}$ deep lake. Hydrologists and hydrogeologists investigate the inflow rate variations, the chemical content and the origin of the karst springs that mainly feed Lake Ohrid besides only small streamlets. Geoscientists focus their research on the evolution of the lake and the neighboring intramontane basins. Paleoclimatologists expect one of the furthest reaching sediment archives for the reconstruction of paleoenvironmental conditions.

This paper concentrates on the tectonic evolution of the Lake Ohrid area and describes tectonic features that are present in the basin surroundings. The geological and geodynamical settings are summarized and the main units are discussed.

\section{Correspondence to: N. Hoffmann} (n.hoffmann@nug.rwth-aachen.de) 


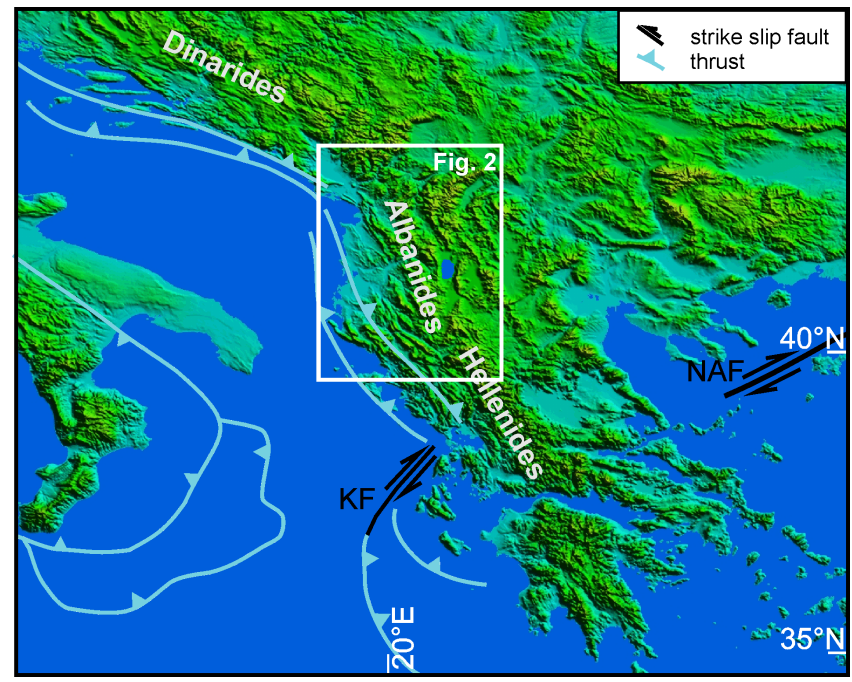

Fig. 1. Overview of the eastern Mediterranean geodynamic situation. Inset shows study area in Fig. $2 . \mathrm{KF}=$ Kefalonia Transform fault, NAF $=$ North Anatolian Fault.

\section{Geodynamic setting}

The geodynamics of Macedonia are mainly controlled by the Northern Hellenic Trench and the North Anatolian Fault Zone (Fig. 1; McKenzie, 1972; Armijo et al., 1999; Papanikolaou et al., 2006). The Lake Ohrid Basin forms the largest of a number of basins in the Dinaride-Alpine mountain belt that stretches along the western shore of the Balkan Peninsula. This belt formed as a result of the Dinaric subduction, still being characterized by a compressional stress regime nowadays (Dumurdzanov et al., 2005). There is at present day no oceanic crust subducting below the Adriatic foreland north of the Kefalonia transform fault. The Ohrid Basin, the Debar Basin to the north, the Korca and Erseka Basins to the south, and the lakes of Great and Small Prespa to the southwest are situated in a basin and range-like geodynamical setting (Figs. 2 and 3). The entire area is controlled by present day E-W extension (Fig. 3). Lake Ohrid Basin marks the transition between the Paleozoic orogen in the east (Pelagonian) and the Mesozoic rocks (Apulian) in the west (Robertson, 2004). Jozja and Neziraj (1998) and Tremblay et al. (2009) describe these units as the Western Macedonian and the Mirdita Ophiolite Zones. Today, the main structural sections of the Eastern Adriatic coast can be subdivided into a compressional coastal domain, followed by a narrow zone of transition west of Lake Ohrid and the extensional domain, in which the Neogene basins formed (see Fig. 3). The roll back of the subducted slap (Fig. 3) leads over time to a westward migration of the entire system. Slab roll back is generally associated with uplift as evidenced in the Gibraltar Zone (Duggen et al., 2003) and shown by fission-track dates of Muceku et al. (2008). This is also evidenced by the westward migration of the NS extensional domain of Eastern Macedo-

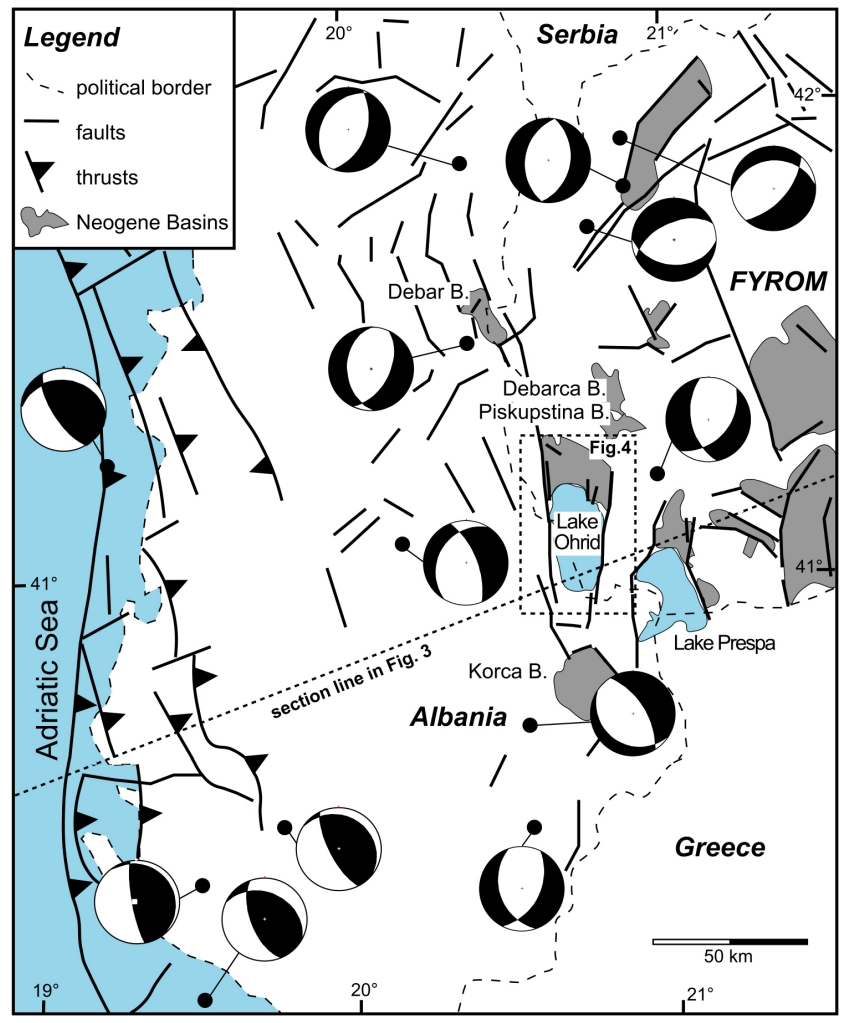

Fig. 2. Fault plane solutions of several earthquakes in the triangle Albania, FYROM and Greece (source: NEIC earthquake data base; CMT focal mechanisms). Note that the change from compressional to extensional domains is associated with Neogene basins (shaded areas) and normal faults (modified from Dumurdzanov et al., 2005). See section in Fig. 3 for structural trends.

nia, which is influenced by the North Anatolian Fault Zone (Fig. 1) with its extension into the Aegean and the initiation of its right-lateral slip in the Early Pliocene (Dumurdzanov et al., 2005, Burchfiel et al., 2008). The older N-trending basins in Eastern Macedonia were disrupted by E-W trending basins, so the faults become younger to the west (Dumurdzanov et al., 2005).

During the Paleozoic, a regional foliation developed in the Cambrian and Devonian units. Thrusts and folds were the dominating deformations during the Mesozoic orogeny, later dominated by normal and strike-slip faulting, mainly in $\mathrm{N}-\mathrm{S}$ direction (Dumurdzanov et al., 2005). Fault patterns of the surroundings of Lake Ohrid indicate a diverse stress history.

Ohrid Basin is a graben structure caused by the E-W directed extension, while the associated Korca and Erseka Basins are halfgrabens bordered by a NW-SE trending normal fault on their eastern side. The sedimentation in the Ohrid Basin began in the Late Miocene with the formation of a pull apart basin, controlled by right-lateral strike-slip movements. Subsidence and further extension account for the major dynamic component since the Pliocene-Pleistocene. Several hundred meters of sediments accumulated since the Late 


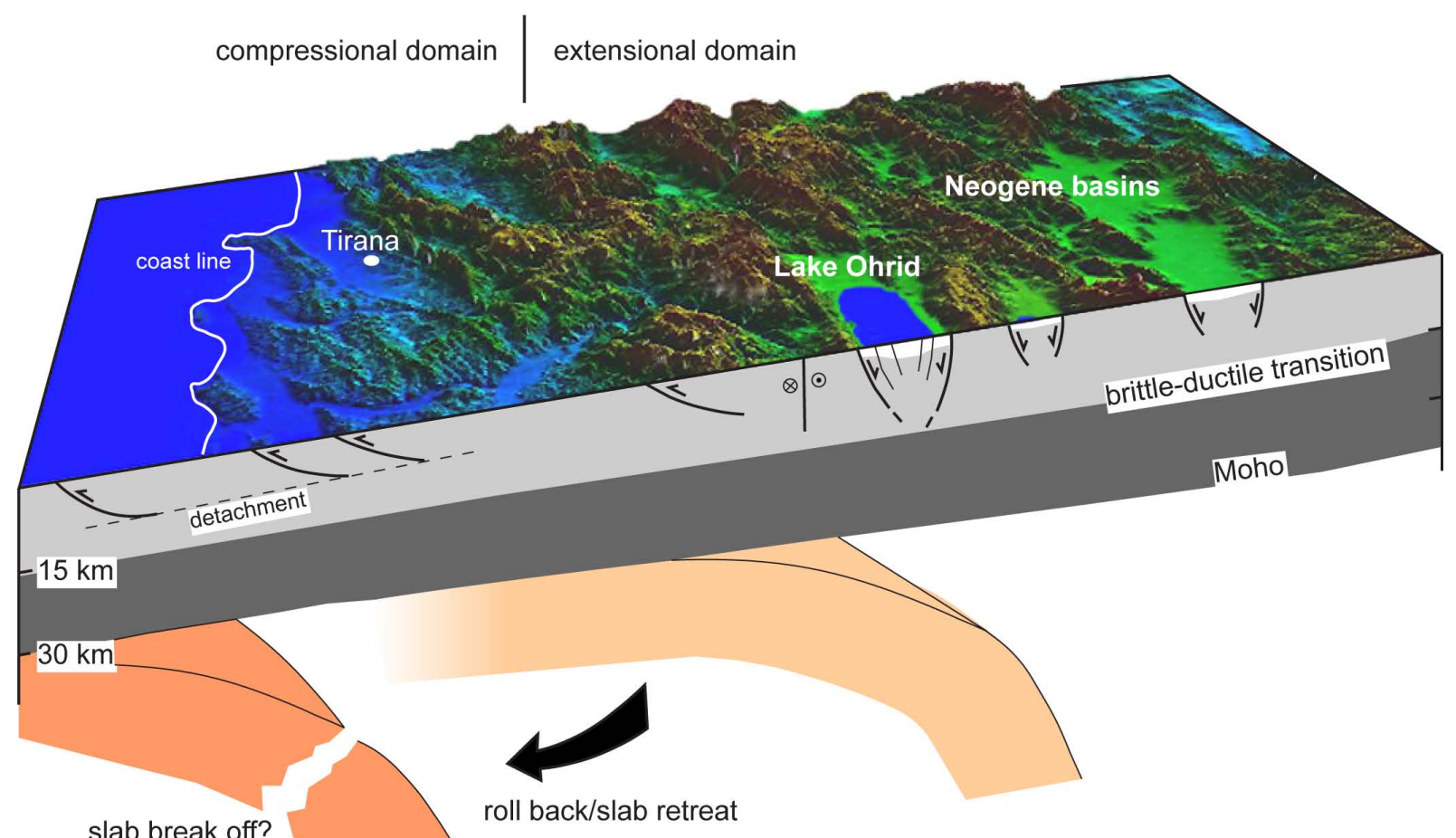

B) PRESENT-DAY

A) EARLY MIOCENE

Fig. 3. Structural cross section from the Adrian coast to the Neogene basins in the Balkanides. The frontal part is characterized by thrusts, whereas the basins are formed within the extensional domain. Note subduction roll-back since Late Miocene. The Moho dips eastward from $30 \mathrm{~km}$ to about $40 \mathrm{~km}$ depth (Anderson and Jackson, 1987; Milivojevic, 1993; Grad et al., 2009).

Miocene (Dumurdzanov et al., 2004). According to Dumurdzanov et al. (2004) the oldest sediments in the lake are probably the Pliocene Piskupstina and Solnje Formations. Today, sedimentation is likely to be compensated by subsidence.

Lake Ohrid Basin is flanked by active N-S trending normal faults that have a clear expression as fault scarps in the present-day landscape. This faulting mechanism can also be derived from recent earthquake data (Fig. 2). Morphological features tend to trend mainly $\mathrm{N}-\mathrm{S}$ in the west of the lake and $\mathrm{N}-\mathrm{S}$ to NNE-SSW in the east. Further sets of NW-SE and E-W lineaments are also present. Latter are most likely related to the $\mathrm{E}-\mathrm{W}$ extension of the basin (Wagner et al., 2008). Active faulting along an E-W trending fault has been described from Lake Prespa (Dumurdzanov et al., 2005). Between the lakes, the Galicica mountain range is separated from the Mali I Thate Mountains in the south by a normal fault that cuts the mountain ridge at $\sim 1500 \mathrm{~m}$ a.s.l. (Aliaj, 2000). Fault surfaces and lineations are preserved in the entire area. Burchfiel et al. (2006, p. 242) estimate present day slip-rates of not more than $2 \mathrm{~mm} / \mathrm{yr}$ on "NNW-striking normal faults and associated strike-slip faults with right-lateral displacement" but with a very high uncertainty due to imprecise GPS data.

\subsection{Seismicity and neotectonics}

In $518 \mathrm{AD}$, an earthquake destroyed the cities of Ohrid and Skopje (110 km NNE of Ohrid) (Petrovski, 2004). The event was so strong that almost the entire city of Ohrid had to be rebuilt, Skopje suffered heavy damages. This is the strongest historical quake to have hit Macedonia. Another strong earthquake in the study area is reported by the ancient historian Procopius (ca. 500-565 AD) who mentioned Lychnidus in his Secret History or History Arcana (Atwater, 1927). Lychnidus is regarded the old name of Ohrid, but there are also workers that place it close to Sveti Naum at the southern shore of the lake (Lempriere, 1838). The text of the Secret History Arcana is an emotional harangue against emperor Justinian and his wife and describes the catastrophe during Justinian times, most probably 526 AD. A local earthquake that destroyed the entire city and left the majority of the inhabitants dead, must have had a magnitude greater than 6 , even taking into account poor building standards and historically (or politically and personally) intended exaggerations. Even if the fatalities were not caused by building collapse due to shaking but resulted of secondary seismic effects like rockfalls, landslides, dry-running wells etc., a mediumstrong event (Michetti et al., 2007) must be assumed. Ambraseys (2009) lists a strong event in $527 \mathrm{AD}$, which would 
fit the historical data of the reign of Justinian. It is not clear whether this event is related to the earthquake of $518 \mathrm{AD}$, which destroyed Ohrid and Skopje or if, due to historical uncertainties, only one event took place. Other significant events occurred in 548, 1673, 1871, 1889, 1896 and 1911 AD (Ambraseys and Jackson, 1990; Goldsworthy et al., 2002; Ambraseys, 2009).

Instrumental seismicity records in the Ohrid area reach back to the early 20th Century. The strongest event ever measured here took place on 18 February 1911. The magnitude 6.6 earthquake (EMS X) occurred in the Ohrid-Korca area in a depth of $15 \mathrm{~km}$ (Milutinovic et al., 1995; Muço, 1998). Burton et al. (2004) list only moderate events (except the 1911 earthquake $)$ in shallow depths $(<60 \mathrm{~km})$ for the study area. Background seismicity is low compared to Greece, Western Albania and the Eastern Macedonia-Bulgaria region. Most recent events are the 23 November 2004, Mw 5.4 earthquake in the Korca region $\left(40.39^{\circ} \mathrm{N}, 20.48^{\circ} \mathrm{E}\right.$; focal depth $\sim 20 \mathrm{~km}$, normal faulting) and the 6 September 2009 , Mw 5.6 event in Albania (shallow focal depth, normal faulting; e.g. EMSC, 2010). The normal faulting mechanism (see Fig. 2) is a result of the E-W extension. Even though hundreds of houses were damaged and some dozens even destroyed, no fatalities were reported. A series of more than 35 aftershocks followed the main shock in the next days. The shallow epicenters in combination with the poor building standards in the region are held responsible for the severe damages. Smaller recent events have shallow epicenters up to $25 \mathrm{~km}$ depth, deeper events are rare. Most of the earthquakes are associated to the fault zones that border the Ohrid Basin (Aliaj et al., 2004). Fault plane solutions of the recent earthquakes fit the geodynamic setting with mainly compression along the Albanian coast and normal faulting mechanisms that contribute to the extensional domain inland (Figs. 2 and 3).

Maximum peak ground accelerations expected for a return period of $500 \mathrm{yr}$ reach from $0.30 \mathrm{~g}$ in the east of Ohrid (Lake Prespa region) to $0.50 \mathrm{~g}$ in the west of the study area (Iben Brahim, 2005). Normal fault length varies between 2$18 \mathrm{~km}$, onshore and within the lake. Besides segmentation of longer faults and taking into account a possible rupture length of approximately $15-18 \mathrm{~km}$, we expect that the normal faults at Ohrid are prone to generate an earthquake of M 6.5-7 (according to Wells and Coppersmith, 1994). However, we are not aware about recurrence periods of these major events in the Lake Ohrid area. Taking all this into account, the Ohrid-Korca area is regarded one of the highest seismic hazard zones in Albania and Macedonia (Aliaj et al., 2004) but only medium among the Balkans (NEIC, 2010; GSHAP, 2010).

\section{Geological overview}

Lake Ohrid Basin, a graben structure, is located at the contact between the Mirdita Ophiolite Zone, one of the internal zones of the Albanides, and the Korabi Zone of the Western Macedonian Zone. In the lake region the Jurassic ophiolites of the Mirdita Zone are thrusted over the units of the Korabi Zone (Fig. 4) during Early-Mid Tertiary (Robertson and Shallo, 2000). The contact of the two zones can be observed south of the Lini Peninsula (Fig. 5) at the western shore of the lake. The geodynamic setting with the Alpine-DinarideAlbanide thrusting in Tertiary and todays extensional regime led to the general impression of a NW-SE striking of the large geological units. While the Shebeniku Ophiolitic Massif of the Mirdita Zone forms part of the SW graben shoulder, Triassic carbonates and clastics of the Korabi zone are widely exposed to the SE and NW of the lake (Fig. 4). At the NE margin of the basin the underlying Paleozoic metamorphic rocks of the Korabi zone are exposed. This thrust-like geological setting is modified by the Tertiary to present extensional regime, which leads to the basin formation and the beginning of flysch and molasse sedimentation.

\subsection{Korabi Zone}

The Korabi Zone (Fig. 4) in the lake area is characterized by Paleozoic, mostly metamorphic and magmatic rocks, which are superposed by Mesozoic Triassic to Early Jurassic limestones (Robertson and Shallo, 2000; Kilias et al., 2001) in the horst shape of an anticline structure, developed between Ohrid and Prespa lakes (Fig. 4). The Devonian metamorphic rocks consist mainly of greywackes and phyllites with a complex metamorphic history. These metamorphic rocks crop out at the NE lake shore around the city of Ohrid. South of the city of Ohrid they are preserved as a tectonic window due to extensive normal faulting (Fig. 4). In the northern part of the Galicica Mountain range, marbleized limestones are preserved locally at the top of the mountains, e.g. NE of the village Kosel (Fig. 5; Dumurdzanov and Ivanovski, 1977). Volcanic activity in this unit is only preserved as Paleozoic granitic intrusions north of Lake Prespa (Dumurdzanov and Ivanovski, 1977). These units are superimposed by Triassic to Early Jurassic platform carbonates of the Galicica Mountains, which consist of mainly intensively folded limestones and locally of dolomites (Fig. 4). The mainly massive and thick limestones are locally thin-bedded and intercalated with radiolarites and cherts, e.g. NE of Ljubanista (Fig. 5). These carbonates of the Galicica Mountains extend to the south of the Mali i Thate Mountain chain (Fig. 5) and are affected by intense karstification. Most parts of the eastern graben shoulder and NW shores of the lake are built up by this Mesozoic units. Along prominent normal faults, like the one at the village of Dolno Konjsko (Fig. 5), south of the city of Ohrid, serpentinites are exposed as isolated blocks in shear lenses. Due to their position in the Korabi Zone their 


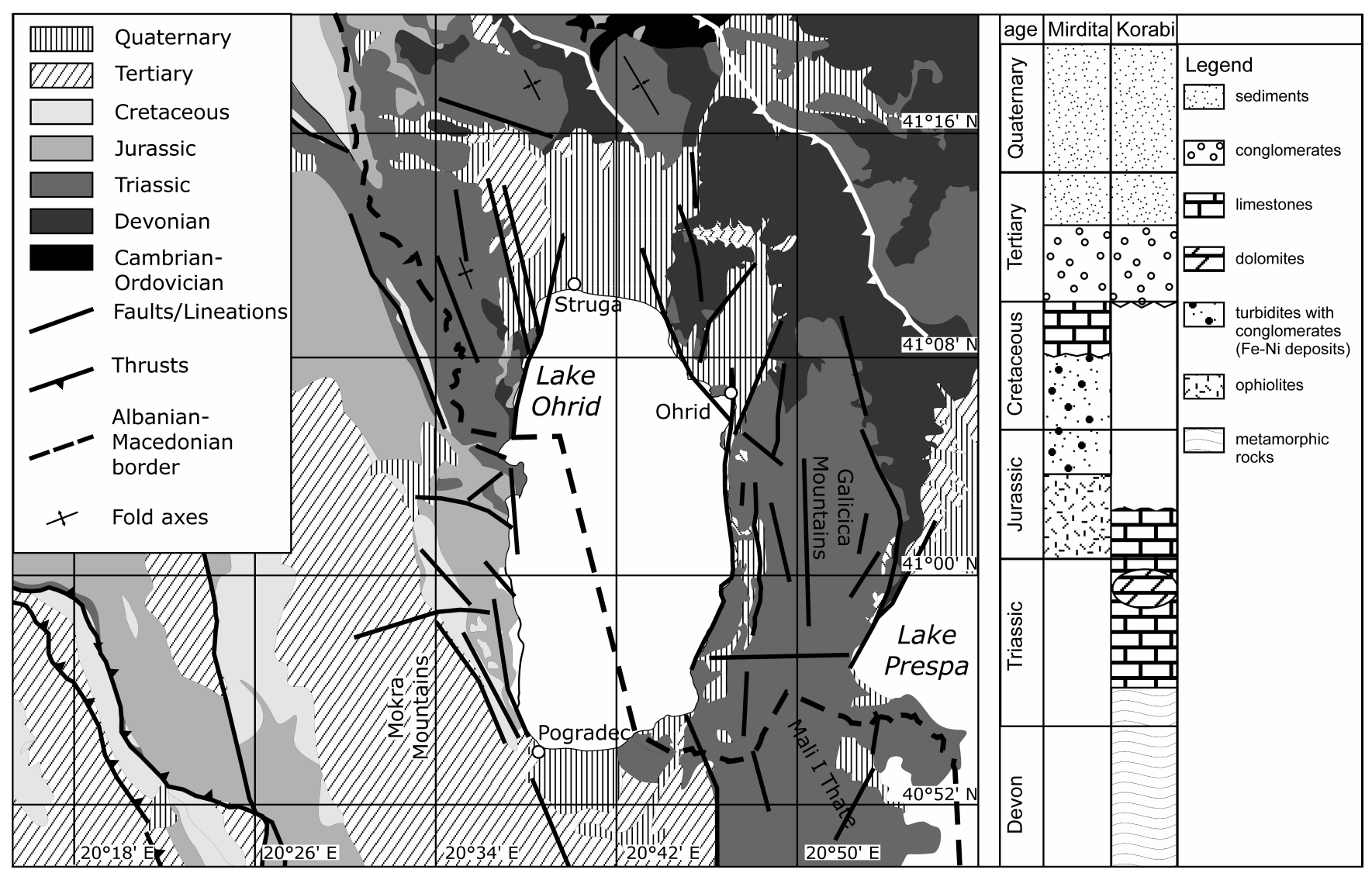

Fig. 4. Left: Geological map of the Lake Ohrid area. Main structural elements are shown. Right: Stratigraphy of Mirdita and Korabi units. Compiled after Dumurdzanov and Ivanovski (1977) and Premti and Dobi (1994).

origin and stratigraphic position is not clear up to now. Furthermore, Mesozoic intrusions of rhyolithes and diabases are preserved in between the limestones and dolomites east of Kosel (Fig. 5).

\subsection{Mirdita Zone}

The Shebenik Ophiolite Complex of the Mirdita Zone (Fig. 4) belongs to the eastern ophiolite belt (Kocks et al., 2007). The genesis and origin of the sub-parallel western and eastern ophiolite belt of the Mirdita Zone is still under discussion (Robertson, 2004; Muceku et al., 2006; Gawlick et al., 2008; Kilias et al., 2010). While west-directed transport of the nappe structures in Tertiary is generally accepted, their origin as far travelled allochthon nappes (Gawlick et al., 2008; Kilias et al., 2010) with origin in the Vardar Zone or autochthon development in an independent Pindos-Mirdita Ocean (e.g. Robertson and Shallo, 2000) are still under debate. The ophiolites of the eastern belt are of Early to Middle Jurassic age (Fig. 4) and show supra-subduction zone (SSZ) and mid-ocean ridge (MOR) affinities in accordance to the model of Bébien et al. (1998) and Hoeck et al. (2002). They consist mainly of lherzolites and gabbros; interlay- ered pyroxenitic dykes and minor harzburgites and serpentinites (Hoeck et al., 2002; Kocks et al., 2007) have been described as well. The upper part of the sequence is dominated by basaltic breccias and turbidites with conglomerates of ophiolitic clastics, which bear Fe-Ni ore deposits. The ore deposits in the lake area were intensely mined in the past. To the west the ultrabasic units of the Shebeniku Ophiolitic Massif are transgressive covered by thin shallow water carbonates of Late Cretaceous age (Fig. 4) with rudists (Jozja and Neziraj, 1998). This transgression is characterized by an angular unconformity. Figure 6a shows the contact of the ophiolite debris above a deeply weathered lateritic horizon and the shallow water limestones. At the western shoreline this contact is often indicated by linear orientated tailings from mining operations. Anyhow, these contacts are not always sedimentary and uniform. Due to intensive normal faulting during the extensional stage the deposits are arranged staircase-like and the contacts are often disturbed today (Fig. 6b). 


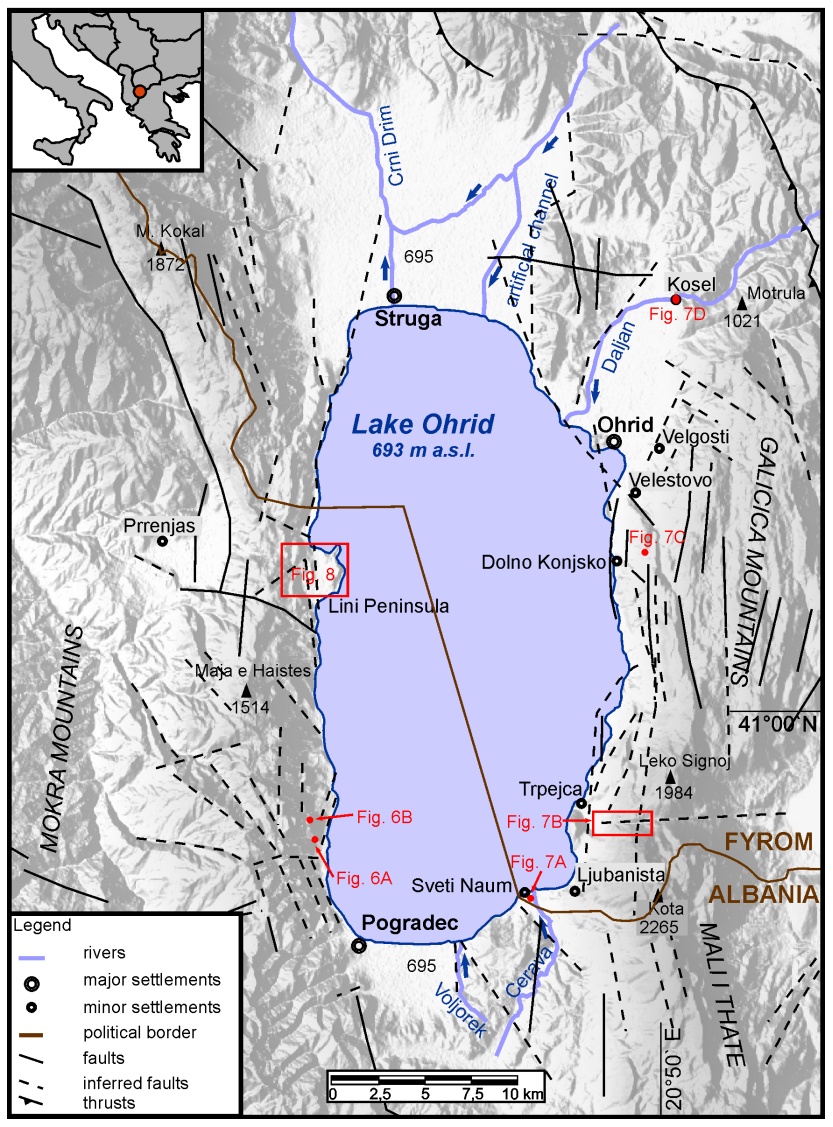

Fig. 5. Geomorphic overview map of Lake Ohrid with main structural features. Red marked areas point to the locations of Figs. 6-8.

\subsection{Syn- and postorogenic development}

During alpine orogeny from the Eocene until Pliocene, flysch and molasse-like sediments were deposited, which are now exposed as deformed nappes (Jozja and Neziraj, 1998). They cover the ophiolitic Mirdita units to the west. Further remains are preserved covering discordant Korabi units in the south of the lake (Fig. 7a) and in the Struga Plain. They consist of Paleocene conglomerates, silt- and sandstones of the flysch, overlain by Neogene molasse clastics, mainly conglomerates, sands and boulder gravels. Molasse outcrops at the lake are located near Pogradec (Pliocene) and west of Prrenjas (Fig. 5; Eocene to Tortonian), which consist of folded and thrusted granite-bearing conglomerates and sandstones. A further outcrop is near Ljubanista close to the southern shore of Lake Ohrid (Fig. 7a), where the river Cerava cuts into Pliocene conglomerates consisting of sands and gravels, which have been transported from Albania and Greece. The deposits are built up of eroded Cenozoic molasse of the Korca Basin, which have been redeposited in the Ohrid Basin. They are superposed discordantly by Pleistocene conglomerates, which have been transported from the heights of Mali I Thate and Galicica Mountains.
The transportation processes were stopped by ongoing subsidence, which divided the Ohrid from the Korca Basin in the Late Pliocene and Early Pleistocene.

SE of Trpejca, Pleistocene carbonate-cemented, coarsegrained angular colluvial sediments form a large and wellpreserved debris cone (Fig. 7b). Other areas are characterized by the formation of huge paleosols, which are for example preserved within the hanging wall of an active normal fault at the eastern graben shoulder NW of Dolno Konjsko (Fig. 7c). The youngest deposits in the Ohrid Basin are the Quaternary plains of Struga in the north and Pogradec in the south. While the plain of Pogradec provides indications for a drying up of shallow lake areas filled with fine grained sediments, the northern plain is build up by gravel and sand strata from river deltas and alluvial fans. North of the city of Ohrid in the village of Kosel the so called Duvalo "volcano" can be observed. The fault-related hydrothermal field with carbon dioxide and hydrogen sulfide exhaling solfatara or fumaroles (geochemical data are not available; Fig. 7d) is situated some kilometers north of the town of Ohrid and stretches along a N20E striking lineament (Arsovsky and Hadžievsky, 1970) in highly alterated phyllites of Devonian age, which are kaolinisated. These rocks bear sulfur, which was mined and used for spa and therapeutic purposes. Today the hydrothermal field is used as a dumpsite and thus the solfatara are buried successively. Further south along the lineament, thermal sulfur-bearing springs occur in the village of Velgosti (Fig. 5). As fumaroles are in general related to former volcanic activity, the area was mapped intensely, but no evidence of volcanic rocks or pyroclastic depositions were found. The geothermal anomaly observed here is most likely related to tectonic activity.

\section{Tectonic history}

The above mentioned three phases of deformation left their imprint in the geological units around Lake Ohrid. The first phase of NW-SE shortening during the Late Cretaceous formed folds and thrust faults (Dumurdzanov et al., 2005), with NW-SE striking fold axes and faults (see Figs. 4 and 5). Younger Cenozoic (Late Miocene) deformation is characterized by normal and strike slip faulting, which is caused by NW-SE shortening and uplift. This lead to the reactivation of inherited faults and subsequently pull apart-like opening of the Ohrid Basin (Dumurdzanov et al. 2005; Ilic and Neubauer, 2005). After Burchfiel et al. (2006), the recent transition zone (today located in Central Albania) between extensional and the compressional regime is evidently marked by right-lateral strike-slip, which can be identified from displacement vectors derived from GPS measurements and geological data. Concerning the westward migration of the deformation domains as explained in Chap. 2, this transition zone is probably responsible for initial dextral strikeslip movement, which leads to a pull apart-like opening of 


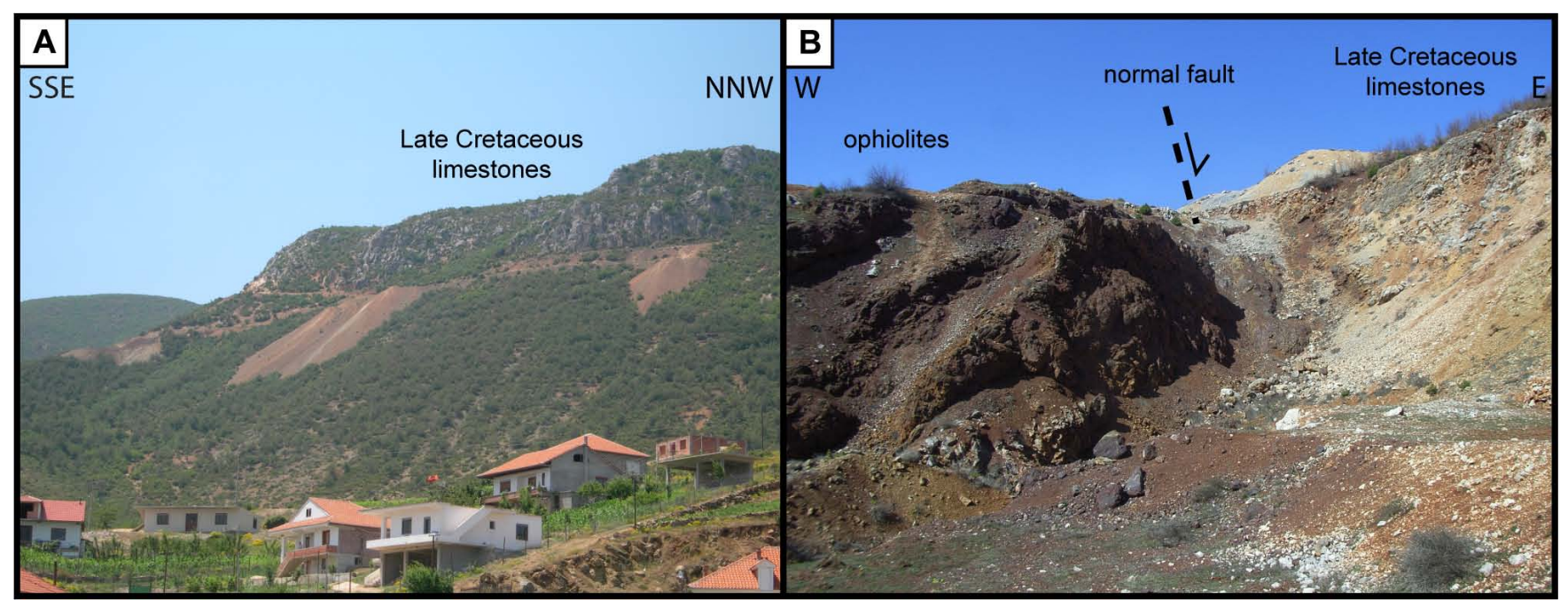

Fig. 6. (A) The contact between Mirdita ophiolites and Late Cretaceous limestones is marked by large tailings (west coast of Lake Ohrid, Albania, view towards SW). (B) Close-up view of a normal fault that bounds the Mirdita ophiolites and the limestones of Late Cretaceous age (Albania, $40^{\circ} 57^{\prime} 48^{\prime \prime} \mathrm{N}, 20^{\circ} 36^{\prime} 22^{\prime \prime} \mathrm{E}$; view towards $\mathrm{N}$ ).

the basin. In addition, E-W trending faults indicate dextral strike-slip movements such as the fault separating the Galicica from the Mali I Thate Mountains (see Chap. 2 and Fig. 7b). The counterpart of the fault can be found south of the Lini Peninsula at the western bank of the lake. Preliminary results of paleostress and fault pattern analysis support the dextral movement as well (Reicherter et al., 2010). From Pliocene to present E-W extension prevails, which leads to local subsidence, the development of $\mathrm{N}-\mathrm{S}$ striking normal faults (Aliaj, 2000) and opening of extensional basins. Muceku et al. (2008) suggest that the change to an extensional regime occurred at about $6 \mathrm{Ma}$.

Figure 8 presents a panoramic view of the surroundings of the Lini Peninsula. En echelon N-S striking faults in ophiolites of the Shebeniku complex at the Lini halfgraben can be seen. The Lini halfgraben is composed of Neogene sediments (Jozja and Neziraj, 1998) whereas the front part of the Peninsular is made up of Middle to Late Triassic limestone. To the west, ophiolites and limestones crop out, where the limestones form the hard cap rock of the sequence and are underlain by the ophiolites. Several sets of normal faults are preserved. The staircased geomorphology gives evidence for several fault generations that become younger to the center of the basin (Reicherter et al., 2010) due to a progressive hangingwall directed migration of activity within the fault zone (Stewart and Hancock, 1994). This can also be seen from the displacement of the Cretaceous limestone caps (Fig. 6a), which protect the ophiolites from erosion. This morphological structure is typical for the basin and also continues into the lake. The west coast has a steeper relief favoring the halfgraben theory of Aliaj (2000).
Seismic surveys in the lake (Lindhorst et al., 2010), preservation of fault scarps and tectonically cut alluvial fans show that the faults get younger towards the lake. Wagner et al. (2008) present hydroacoustic data that clearly show the extension of the $\mathrm{N}-\mathrm{S}$ trending normal faulting that deforms the lake sediments. This step-like expression of extensional deformation is typical for tectonic landscapes as promoted by Michetti et al. (2005). Usually, the youngest elements become activated by neotectonic activity; however, a reactivation of older faults may also occur. Different fault systems have been investigated in the vicinity of the lake. From relative ages of these faults the $\mathrm{N}-\mathrm{S}$ trending extensional structures are definitively the youngest. These preliminary results fit well to the model of the first three deformation phases (from 4 deformation phases in total) published by Ilic and Neubauer (2005) from the Dinarides area (Internal Dinarides to the north). The oldest deformation phase is dominated by $\mathrm{E}-\mathrm{W}$ shortening and characterized by reverse and strike-slip faults in Eocene, followed by NE-SW contraction with N/NW-trending dextral and W/WSW-trending sinistral strike-slip faults in Oligocene to early Miocene. In Early to Middle Miocene, NE-SW extension leads to mainly $\mathrm{NW}$-trending normal faults, and finally $\mathrm{N}-\mathrm{S}$ shortening with dextral wrenching, resulting in NW-trending dextral and NEtrending sinistral strike-slip faults.

Along the slopes of the Galicica Mountains and below the wind gap shown in Fig. $7 \mathrm{~b}$ several generations of postglacial scarps can be identified, which form characteristic features in the landscape. According to Papanikolaou et al. (2005) they give evidence for a subsidence rate, which is today not outpaced by erosion or sedimentation and indicates active subsidence. Further north at the Galicica Mountains close to Dolno Konjsko a post-glacial paleosol crops out (Fig. 7c), 


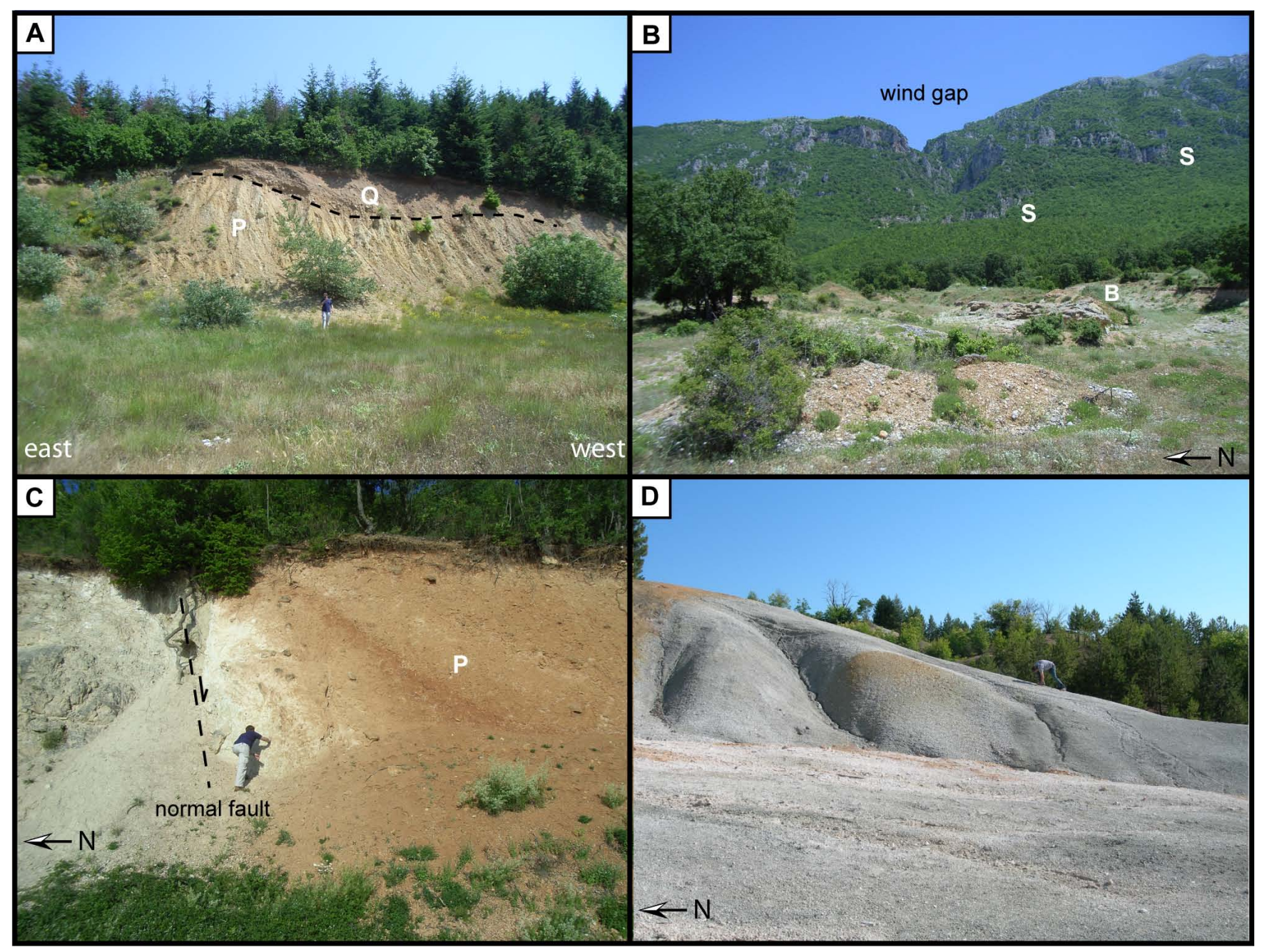

Fig. 7. (A) Pliocene conglomerates (P) of the river Cerava near Sveti Naum monastery (view towards S), which are overlain unconformably by Pleistocene conglomerates (Q). (B) Galicica mountain front with stepped fault scarps (S) and a "wind gap". In the foreground, carbonatecemented colluvial breccias (B) can be seen (view towards E). (C) Active normal fault with a dragged paleosol (P) near Ohrid (view towards E). (D) "Duvalo" hydrothermal field near Kosel, note completely altered and sulfur-impregnated phyllites (view towards E).

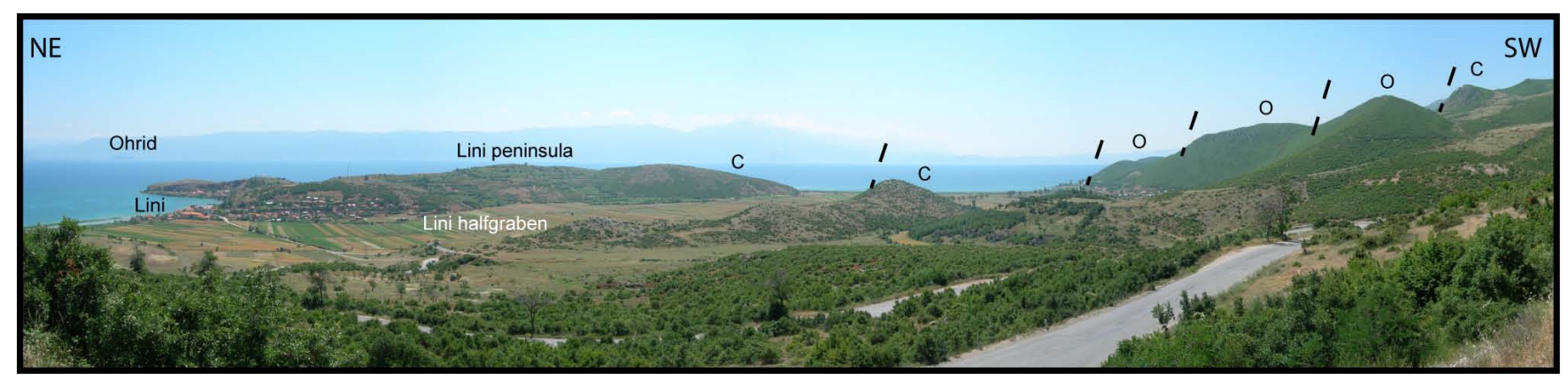

Fig. 8. Panoramic view of the Lini halfgraben (Albania; view towards SE), note the stepped landscape due to normal faulting of the ophiolites (O) and Late Cretaceous limestones and Triassic carbonates (C). 
which is offset against Triassic limestones. The NE-SW striking fault shows several meters of displacement. The paleosols and the overlying sediments were dragged into the fault zone, forming a wedge. On top sediments accumulated unconformably. This outcrop illustrates the neotectonic activity of today.

\section{Conclusions}

The different deformation phases that affected the study area led to a highly complex fault pattern. Slickensides and other markers of tectonic movement are locally preserved at fault scarps and allow reconstructing the deformation history (Reicherter et al., 2010). Geomorphological features like the wind gap, deformed paleosols and the stepped landscape are present day expressions of the basin formation process since Late Cretaceous. The occurrence of the hydrothermal field near Kosel is most likely fault related since no other hints for volcanic activity in younger times have been found. Field observations and recent earthquake data let us conclude that the $\mathrm{N}-\mathrm{S}$ striking faults that border Lake Ohrid are the active elements today and that extension is ongoing. The entire lake area can be classified as a tectonic landscape. Further investigations are needed to refine the chronological resolution and to precisely date the neotectonic activity.

Acknowledgements. This study was carried out in the frame of ICDP. We thank the Deutsche Forschungsgemeinschaft (grant Re 1361/10) and the RWTH Aachen University for financial support. Thanks are extended to our partners of FYROM, namely Zoran Spirkovski (Ohrid) and of Albania, Shyqyri Aliaj and Andon Grazhdani (Tirana).

Edited by: B. Wagner

\section{References}

Aliaj, S.: Neotectonics and seismicity in Albania, in: Geology of Albania, edited by: Meco, S., Aliaj, S., and Turku, I., Beitr. Regional. Geol. Erde, 28, 135-178, 2000.

Aliaj, S., Adams, J., Halchuk, S., Sulstarova, E., Peci, V., and Muço, B.: Probabilistic seismic hazard maps for Albania, 13th World Conf. Earthquake Engineering, Vancouver, BC, Canada, paper no. 2469, 14 pp., 2004.

Ambraseys, N. and Jackson, J.: Seismicity and associated strain of Central Greece between 1890 and 1988, Geophys. J. Int., 101, 663-709, 1990.

Ambraseys, N.: Earthquakes in the Mediterranean and Middle East, Cambridge University Press, New York, 2009.

Anderson, H. and Jackson, J.: Active tectonics of the Adriatic Region, Geophys. J. Roy. Astr. S., 91, 937-983, 1987.

Armijo, D., Meyer, B., Hubert, A. and Barka, A.: Westward propagation of the North Anatolian fault into the northern Aegean: Timing and kinematics, Geology, 27, 267-270, 1999.
Arsovsky, M. and Hadžievsky, D.: Correlation between neotectonics and the seismicity of Macedonia, Tectonophysics, 9, 129142, 1970.

Atwater, R.: Procopius of Ceasarea: The Secret History, P. Covici, Chicago, 1927 and Covici Friede, New York, 1927, reprinted, University of Michigan Press, Ann Arbor, MI, 1961, with indication that copyright had expired on the text of the translation, 135-136, 1927.

Bébien, J., Shallo M., Manika, K. and Gega, D.: The Shebenik massif (Albania), a link between MOR- and SSZ-type ophiolites? Ofioliti, 23, 7-15, 1998.

Burchfiel, B. C., King, R. W., Todosov, A., Kotzev, V., Dumurdzanov, N., Serafimovski, T., and Nurce, B.: GPS results for Macedonia and its importance for the tectonics of the Southern Balkan extensional regime, Tectonophysics, 413, 239-248, 2006.

Burchfiel, B. C., King, R. W., Nakov, R., Tzankov, T., Dumurdzanov, N., Serafimovski, T., Todosov, A., and Nurce, B.: Patterns of Cenozoic extensional tectonism in the South Balkan extensional system, Nato. Sci. S. Ss. Iv. Ear., 2008.

Burton, P. W., Xu, Y., Qin, C., Tselentis, G. A., and Sokos, E.: A catalogue of seismicity in Greece and the adjacent areas for the twentieth century, Tectonophysics, 390, 117-127, 2004.

Duggen, S., Hoernle, K., van den Bogaard, P., Rüpke, L. and Morgan, J.: Deep roots of the Messinian salinity crisis, Nature, 422, 602-606, 2003.

Dumurdzanov, N. and Ivanovski, T.: Geological map of the Socialist Federal Republic of Yugoslavia, Sheet Ohrid, Geological Survey Belgrad, 1977.

Dumurdzanov, N., Serafimovski, T., and Burchfiel, B. C.: Evolution of the Neogene-Pleistocene basins of Macedonia, Geological Society of America Digital Map and Chart Series 1, Skopje, 2004.

Dumurdzanov, N., Serafimovski, T., and Burchfiel, B. C.: Cenozoic tectonics of Macedonia and its relation to the South Balkan extensional regime, Geosphere, 1, 1-22, 2005.

EMSC: European Mediterranean Seismological Centre, www. emsc-csem.org, last access: 27 October 2010.

Gawlick, H. J., Frisch, W., Hoxha, L., Dumitrica, P., Krystyn, L., Lein, R., Missoni, S., and Schlagintweit, F.: Mirdita Zone ophiolites and associated sediments in Albania reveal Neothetys Ocean origin, Int. J. Eaerth. Sci., 97, 865-881, 2008.

Goldsworthy, M., Jackson, J., and Haines, J.: The continuity of active fault systems in Greece, Geophys. J. Int., 148, 596-618, 2002.

Grad, M., Tiira, T. and ESC Working Group: The Moho depth map of the Euopean Plate, Geophys. J. Int., 176, 279-292, 2009.

GSHAP: Global Seismic Hazard Assessment Program, www. seismo.ethz.ch/gshap, last access: 27 October 2010.

Hoeck, V., Koller, F., Meisel, T., Onuzi, K., and Kneringer, E.: The Jurassic South Albanian ophiolites: MOR- vs. SSZ-type ophiolites, Lithos, 65, 143-164, 2002.

Iben Brahim, A.: Assessment of seismic risk maps and evaluation of seismic vulnerability of historical building heritage in the Mediterranean area, Report on WP3 of the PROHITECH Programme, FP62002-INCO-MPC-1, Iben Brahim A., Rabat, www.prohitech.com, last access: 15 June 2010, 2005.

Ilic, A. and Neubauer, F.: Tertiary to recent oblique convergence and wrenching of the Central Dinarides: constraints from a palaeostress study, Tectonophysics, 410, 465-484, 2005. 
Jozja, N. and Neziraj, A.: Geological heritage conservation of Ohrid Lake, Geol. Balcanica, 28, 91-95, 1998.

Kilias, A., Tranos, M, Mountrakis, D., Shallo, M., Marto, A., and Turku, I.: Geometry and kinematics of deformation in the Albanian orogenoc belt during Tertiary, J. Geodyn., 31, 169-187, 2001.

Kilias, A., Frisch, W., Avgerinas, A., Dunkl, I., Falalakis, G., and Gawlick, H. J.: Alpine architecture and kinematics of deformation of the northern Pelagonian nappe pile in the Hellenides, Austr. J. Earth. Sci., 103(1), 4-28, 2010.

Kocks, H., Melcher, F., Meisel, T., and Burgath, K. P.: Diverse contributing sources to chromitite petrogenesis in the Shebenik Ophiolitic Complex, Albania: evidence from new PGE and Osisotope data, Miner. Petrol., 91, 139-170, 2007.

Lempriere, D. D.: Bibliotheca Classica, W. E. Dean, New York, 186-192, 1838.

Lindhorst, K., Vogel, H., Krastel, S., Wagner, B., Hilgers, A., Zander, A., Schwenk, T., Wessels, M., and Daut, G.: Stratigraphic analysis of lake level fluctuations in Lake Ohrid: an integration of high resolution hydro-acoustic data and sediment cores, Biogeosciences Discuss., 7, 3651-3689, doi:10.5194/bgd-7-3651-2010, 2010.

McKenzie, D.: Active Tectonics of the Mediterranean Region, Geophys. J. R. Astr. Soc., 30, 109-185, 1972.

Michetti, A. M. and Hancock, P. L.: Paleoseismology: understanding past earthquakes using Quaternary geology, J. Geodyn., 24, 3-10, 1997.

Michetti, A. M., Audemard, F. A., and Marco, S.: Future trends in Paleoseismology: integrated study of the seismic landscape as a vital tool in seismic hazard analyses, Tectonophysics, 408, 3-21, 2005.

Michetti, A. M., Esposito, E., Guerrieri, L., Porfido, S., Serva, L., Tatevossian, R., Vittori, E., Audemard, F., Azuma, T., Clague, J., Comerci, V., Gürpinar, A., McCalpin, J., Mohammadioun, B., Mörner, N. A., Ota, Y., and Roghozin, E.: Environmental Seismic Intensity Scale - ESI 2007, Memorie Descrittive della Carta Geologica D'Italia, 74, 41, 2007.

Milivojevic, M. G.: Geothermal model of earth's crust and lithosphere for the territory of Yugoslavia: some tectonic implications, Stud. Geophys. Geod., 37, 265-278, 1993.

Milutinovic, Z. V., Trendafiloski, G., and Olumceva, T.: Disaster preparedness planning for small and medium size hospitals based on structural, nonstructural and functional vulnerability assessment, World Health Organisation, Institute of Earthquake Engineering and Engineering Seismology, Skopje, 1995.

Muceku, B., Mascle, G., and Tashko, A.: First results of fission-track thermochronology in the Albanides, in:Tectonic Development of the Eastern Mediterranean Region, Geol. Soc. Lond. Sp. Publ, edited by: Robertson, A. H. F. and Mountrakis, D., 260, 539-556, 2006.
Muceku, B., van der Beek, P., Bernet, M., Reiners, P., Mascle, G. and Tashko, A.: Thermochronological evidence for MioPliocene late orogenic extension in the north-eastern Albanides (Albania), Terra Nova, 20, 180-187, 2008.

Muço, B.: Catalogue of ML 3,0 earthquakes in Albania from 1976 to 1995 and distribution of seismic energy released, Tectonophysics, 292, 311-319, 1998.

NEIC - National Earthquake Information Center: neic.usgs.gov, last access: 27 October 2010.

Papanikolaou, I. D., Roberts, G. P., and Michetti, A. M.: Fault scarps and deformation rates in Lazio-Abruzzo, Central Italy: comparison between geological fault slip-rate and GPS data, Tectonophysics, 408, 147-176, 2005.

Papanikolaou, D., Alexandri, M., and Nomikou, P.: Active faulting in the north Aegean basin, Postcollisional Tectonics and Magmatism in the Mediterranean Region and Asia, Geol. Soc. Am. S., 409, 189-209, doi:10.1130/2006.2409(11), 2006.

Petrovski, J. T.: Damaging effects of July 26, 1963 Skopje Earthquake, website:www.meseisforum.net, Middle East Seismological Forum (MESF) CYBER GEOSCI, 2, last access: 15 June 2010, 2004.

Premti, I. and Dobi, A: A geological map of Albania, Sheet Masivi Ultrabazik i Shebenik-Pogradecit, Inst. Stud. Proj. Gjeologjike, Tirana, 1994.

Reicherter, K., Hoffmann, N., Lindhorst, K., Krastel-Gudegast, S., Fernández-Steeger, T., and Wiatr, T.: Active basins and neotectonics: morphotectonics of the Lake Ohrid Basin (FYROM/Albania), ZDGG, submitted, 2010.

Robertson, A. and Shallo, M.: Mesozoic-Tertiary tectonic evolution of Albania in its regional Eastern Mediterranean context, Tectonophysics, 316, 197-254, 2000.

Robertson, A.: Development of concepts concerning the genesis and emplacement of Tethyan ophiolites in the Eastern Mediterranean and Oman regions, Earth Sci. Rev., 66, 331-387, 2004.

Stankovic, S.: The Balkan Lake Ohrid and Its Living World, Monographiae Biologicae IX, Uitgeverij Dr. W. Junk b.v. Publishers, The Hague, 357 pp., 1960.

Stewart, I. S. and Hancock, P. L.: Neotectonics, in: Continental Deformation, edited by: Hancock, P. L., 370-409, 1994.

Tremblay, A., Meshi, A., and Bédard, J. H.: Oceanic core complexes and ancient oceanic lithosphere: insights from Iapetan and Tethyan ophiolites (Canada and Albania), Tectonophysics, 473, 36-52, 2009.

Wagner, B., Reicherter, B., Daut, G., Wessels, M., Matzinger, A., Schwalb, A., Spirkovski, Z., and Sanxhaku, M.: The potential of Lake Ohrid for long-term palaeoenvironmental reconstructions, Palaeogeogr. Palaeocl., 259, 341-356, 2008.

Wells, D. L. and Coppersmith, K. J.: New Empirical Relationships among Magnitude, Rupture Length, Rupture Width, Rupture Area and Surface Displacement, B. Seismol. Soc. Am., 84, 974-1002, 1994. 